\title{
Arap İsyanları Sonrasında Ortadoğu'da Vekalet Savaşları: Yemen Örneği
}

\author{
Proxy Wars in the Middle East After the Arab Uprisings: Case of \\ Yemen
}

Veysel KURT $^{*}$

Öz

$\mathrm{Bu}$ çalışma 2011 sonrasında Yemen'deki siyasal değişim ve çatışma sürecine odaklanmaktadır. Bazı dönüm noktalarını göz önünde bulundurarak çatışma sürecinin hangi formlara büründügüunü belirleme iddiasındadır. Bu bağlamda çalışma, 2011 yılında rejim değişimi talepleri ile başlayan ayaklanmaların 2014 yılının başından itibaren çatışma eksenli bir vekalet savaşına dönüştüğünü ve halen bu zeminde seyrettiğini savunmaktadır. Geçiş sürecini yönetmek üzere 2013 yılında oluşturulan Ulusal Diyalog Konferansı (UDK)'nın sonuçlarını kabul etmeyen çeşitli aktörlerin yeniden çatışma sürecini başlatmaları bu anlamda bir dönüm noktası olarak kabul edilmektedir. 2014 yılından itibaren oluşan güç boşluğunda çatışma yerel güçler arasında şiddetlense de uluslararası aktörlerin desteği ve doğrudan müdahalesi daha görünür bir seviyeye gelmiştir. Çalışma Yemen'deki vekalet savaşının uluslararası ve bölgesel aktörleri olarak İran, Suudi Arabistan/Birleşik Arap Emirlikleri (BAE) ve Amerika Birleşik Devletleri (ABD)'yi; yerel aktörler olarak da, Husiler (Ensarullah), Abdu Rabbu Mansur Hadi'ye bağlı hükümet güçleri ve Yemen El-Kaidesi olarak kabul etmektedir. Söz konusu vekalet savaşında taraflar Suudi Arabistan ile ittifak halindeki Hadi güçleri ile İran İran ve yerel vekilleri arasında bir mücadele söz konusudur. ABD ise hükümetle koordinasyon halinde El-Kaide’ye karşı operasyonlar yürütmektedir.

Anahtar Kelimeler: Vekalet Savaşı, Yemen, İran, Suudi Arabistan, ABD, Husiler, El-Kaide

\section{Abstract}

This study focuses on the political change and conflict period in Yemen since 2011. It aims to define how the conflict period is formed by considering the turning points of the conflict. The study argues that the rebellions that started for regime change in 2011 in Yemen turned to a proxy war after January 2014 and that they are still on this ground. The National Dialogue Coalition, which was founded in 2013 to govern the transition period. However its failure at the beginning of 2014, is considered a turning point in this sense. In the power gap that has emerged since this date, the conflict has intensified among the local powers, but the support and direct intervention of international actors has come to a more visible level. The study assumes Iran, Saudi Arabia/United Arab Emirates and the United States as the international actors, and Houthis (Ansarullah), former regime forces and Yemen al-Qaeda as the local forces of the proxy war. The proxy war is a consequence of struggle between Iran and Saudi Arabia.

* Dr. Öğr. Üyesi, İstanbul Medeniyet Üniversitesi, veysel.kurt@medeniyet.edu.tr, Orcid: 0000-0003-4619-4018 
USA as an international actor, carry out military operation against Al-Qaide forces in coordination with Yemeni government.

Keywords: Proxy war, Yemen, Iran, Saudi Arabia, USA, Houthis, Al-Qaeda

\section{Giriş}

İran ile Suudi Arabistan - özellikle 1979 sonrasında - Ortadoğu'da iki rakip güç olarak değerlendirilir. Mezhepsel ayrışma temelindeki ideolojik gerilimler, petrol ve OPEC çerçevesinde ortaya çıkan ekonomik rekabet ve Basra Körfezi üzerindeki güç mücadelesi iki ülke arasındaki rekabetin çeşitli düzeylerdeki yansımalarıdır (Özev, 2016, s.87). 1979 İran devrimi sonrasında ABD’nin Ortadoğu politikası da bu iki güç arasındaki ayrıştırmayı derinleştiren bir rol oynamıştır. $\mathrm{Bu}$ iki güç, rekabetlerini yürütürken hem ideolojik hem de materyal araçlar kullanmaktadırlar. Konvansiyonel düzeyde bir savaş yaşamayan bu iki ülkenin 1979'dan sonra en çok kullandığ araçlar ise ideolojik/mezhepsel unsurlar ile çeşitli 'vekil' aktörler olmuştur. 1979 devrimi sonrasında İran Ortadoğu'daki devlet altı çeşitli gruplar ve partilerle ilişkisini yoğunlaştırmıştır. $\mathrm{Bu}$ durum, Bahreyn ve Yemen gibi ülkelerle ittifak halinde olan Suudi Arabistan ve diğer Körfez ülkeleri tarafından bir tehdit olarak kabul edilmişsir. 1981'de kurulan Körfez İşbirliği Konseyi (KİK) bu tehdide karşı geliştirilen işbirliğinin kurumsallaşmasıdır.

İran ile Körfez ülkeleri arasındaki gerilim Ortadoğu siyasetinin temel analiz konularından biri olmuştur. Çoğu zaman mezhepsel ya da ideolojik bir zeminde seyreden bu gerilim 2010 yılı sonunda başlayan Arap isyanları ile yeni bir form kazanmıştır. Bu isyanların patlak vermesi ile birlikte ideolojik/mezhepsel düzeydeki karşıtlıklar iktidar mücadelesi bağlamında çatışmalara dönüşmüştür. Ancak gözden kaçırılmaması gereken nokta şudur: bu çatışmalar Yemen, Libya ve Suriyede iç savaştan vekalet savaşına doğru evrilmiştir.

Vekalet savaşının yaşandığı ülkelerin hiç birinde olmadığı gibi, Yemen'deki çatışmanın da tarafları yalnızca yerel aktörler değildir. Her bir aktörün bir uluslararası ya da bölgesel güçle işbirliği söz konusudur. Bu iş birliği de yalnızca finansal destek ya da silah yardımı ile sınırlı değildir. Dahası bu işbirliği eşit ortaklar arasında gerçekleşen bir ilişki değildir; yerel güçler, uluslararası aktörlerin etkinlik alanlarını genişletmek üzere izlediği stratejilerin yerel ortaklarıdır. Yerel güçler bu işbirliği sayesinde ilgili ülkede iktidar olmak için avantaj arayışı peşindedir. Uluslararası aktörler ise yerel aktörlerle kurdukları işbirliği sayesinde etkinlik alanlarını genişletme ve rakiplerini zayıflatma stratejisi izlemektedirler. Bu stratejinin başarılı olması durumunda yerel aktörler lehine sonuçlar ortaya çıkmış olacak ve yeni bir müttefik kazanmış olacaklardır.

$\mathrm{Bu}$ çıkarsama Yemen söz konusu olduğunda daha da geçerli olmaktadır. Yemen Cumhurbaşkanı Ali Abdullah Salih, 22 Kasım 2011'de KİK'in kontrolünde görevini bırakmayı kabul etmiş ve bir geçiş süreci başlamıştır. Ancak geçiş sürecinin başarısız olması ile 2014 yılının başından itibaren Yemen'de yeni bir çatışma dalgası başlamıştır. Bu yeni süreçte çatışma basit bir iktidar mücadelesi ya da iç savaş değil, uluslararası ve bölgesel aktörlerin yerel aktörlerle işbirliği yaptığı bir vekalet savaşına dönüşmüştür. İran’ın Husiler ile Suudi Arabistan’ın da Hadi’ye bağlı güçler ve çeşitli 
aşiretlerle kurduğu ittifak vekalet savaşının tipik bir örneğini oluşturmuştur. Zaman zaman ittifaklar arası geçişler yaşansa da bu durumun çatışmanın karakterini ve seyrini değiştirmemiştir. Ali Abdullah Salih'in önce Suudi Arabistan sonrasında Husiler'le işbirliği yapması ve sonra tekrardan Suudi Arabistan/BAE ittifakına yönelmesi (Albahesh, 2018) bu açıdan çarpıcı bir örnektir. Yakın bir döneme kadar birlikte hareket ettiği Husiler tarafından öldürülmesi Yemen'de değişen ittifaklara dair önemli bir göstergedir. ABD’nin El-Kaide’ye karşı hükümetle koordinasyon halinde askeri operasyonlar yürütmesi dolayısıyla bu vekalet savaşının bir tarafını oluşturmuştur.

Çatışmanın vekalet savaşına evrilmesinin ana sebebi İran ile Suudi Arabistan arasındaki gerilimin yatışmaması ve Salih sonrası ülkede oluşan güç boşluğunu bir fırsata çevirerek Yemen üzerinde etkinlik kurma çabalarını hızlandırmasıdır. Bu durum yerel aktörler için zaten on yıllardır farklı düzeylerde işbirliği yaptıkları bu bölgesel güçlerle ortak hareket etmelerine imkan tanımıştır.

$\mathrm{Bu}$ şartlar temel olarak alındığında Yemen'deki çatışma sürecinin vekalet savaşı kavramı ile açıklanması mümkün olmaktadır. Çalışma boyunca Yemen'deki değişim ve çatışma süreci kronolojik bir tasvire tabi tutulmamakta, bunun yerine vekalet savaşının ortaya çıkışı, çatışmalı sürece evrilmesi, tarafları ve sonuçları incelenmektedir. Çalışma, iki temel kısımdan oluşmaktadır. İlk kısımda vekalet savaşına dair kavramsal tartışma okuyucuya sunulmuştur. Vekalet savaşının farklı dönemlerdeki kullanımı tartş̧ılmakta ve kavramın işaret ettiği anlamların izi sürülmüştür. Ayrıca kavramın Ortadoğu bölgesine yansımaları ele alınmıştır. Çalışmanın ikinci kısmı ise 2011 yllının başında Yemen'de başlayan isyanların vekalet savaşına dönüşüm süreci analiz edilmektedir. Bu çerçevede Yemen’deki vekalet savaşının tarafları ve bu taraflar arasındaki işbirliği ve çatışmaların evrimi süreç takibi bağlamında açıllanmaktadır.

\section{Vekalet Savaşına Dair Kavramsal Tartışma}

Vekalet savaşları, Arap isyanları sonrasında özellikle Suriye özelinde sıklıkla kullanılan bir tabir olmakla birlikte kökenleri çok eskiye giden ve fakat kavramsal düzeyde Soğuk Savaş döneminde tartışılmış bir kavramdır. Genellikle SSCB ile ABD’nin doğrudan savaşmak yerine üçüncü bir ülkede kendi çıkarları adına yürüttükleri mücadele için kullanılmıştır (Marshall, 2016, s.185). Burada dikkat edilmesi gereken nokta şudur: ABD ile SSCB'nin üs kurdukları ya da asker konuşlandırdıkları her ülke bir vekalet savaşı alanı değildi. Towle’ye göre (1981, s.23) çoğu zaman bu durum ittifak ilişkisinden kaynaklanmaktaydı. Dahası, süper güçlerin konuşlandığ ülkeler için bu ittifak ilişkisi, ilgili ülkelerin işgale uğraması durumunda yardım almanın en iyi garantisiydi.

Özellikle nükleer savaş tehlikesi dolayısıyla çatışmanın lokal düzeyde tutulmasının bir formülü olarak değerlendirilmiştir. ABD ve SSCB’nin doğrudan müdahil olmadıkları Süveyş Krizi’ndeki rolleri, Küba Krizi ve SSCB’nin Afganistan’ı işgali sonrasında ABD’nin yerel direniş güçlerine sağladığı silah, mühimmat ve finansal destek vekalet savaşlarının farklı örneklerini oluşturmuştur. Gaddis (1990) Soğuk Savaş döneminde iki süper güç ABD ile SSCB’nin birbiri ile doğrudan bir savaşa girmemesinin nedenlerini şu şekilde özetlemiştir: Uluslararası sistemin yapısı, coğrafi 
mesafe ve nükleer savaş tehdidi. ABD ve SSCB'nin nükleer bir çatışmayı göze almamaları, bu iki gücü farklı bölgelerde hesaplaşmaya itmişti. Böylece bu iki güç etkinlik kurma yarışlarını sürdürürken, büyük felaketler doğurabilecek nükleer çatışmadan kaçınmış oldular.

Soğuk Savaş döneminde vekalet savaşı kavramına yönelik akademik düzeyde en çok kullanılan tanımlardan biri ünlü siyaset bilimci Karl Deutscha aittir. Deutsch (1980, s.102) vekalet savaşını "iki dış gücün, üçüncü bir ülkede, bu ülkenin silahlı gücünü ve diğer kaynaklarını, kendi çıkarları, hedefleri ve stratejileri doğrultusunda yürüttükleri uluslararası bir çatışma” olarak tanımlar. Bu tanımın en dikkat çekici özelliği çatışmanın uluslararası niteliğine yapılan vurgudur. Bu bağlamda dış güçlerin hedefini ve stratejilerini fazlasıyla merkeze alırken, işbirliği yaptıkları yerel güçlerin (hükümet ya da devlet dışı aktörlerin) rollerini gözden kaçırmaktadır.

Soğuk Savaşın sona ermesi ile birlikte yaşanan sistemik dönüşüm, savaş ve çatışmanın hem sayısal hem de niteliksel düzeylerine de yansımıştır (Eker, 2015). Bazı teorisyenler savaş ve çatı̧̧maların medeniyetler düzeyinde yaşanacağı iddiasını dile getirirken (Huntington, 1993), diğer bazı araştırmacılar ise dünyanın farklı bölgelerinde başlayan etnik çatışmalara dikkat çektiler (Rabushka ve Shepsle, 2009; Fearon ve Laitin, 2003; Alptekin, 2017). Buna karşın Soğuk Savaş sonrasındaki konvansiyonel savaşlarda \%50 oranında bir düşüş olması ise (Tertrais, 2012, s.8) çatışmaların azaldığına değil, karakterindeki değişime işaret etmektedir. Bu anlamda devletler arası konvansiyonel savaşların yerini vekalet ve bütün çatışma düzeylerini içinde barındıran hibrit savaşları almaya başladığını söylemek mümkündür. Bu durum aynı zamanda devlet dışı silahlı aktörlerin Soğuk Savaş dönemine nazaran daha fazla alan kazanmaya ve çatışmalarda daha fazla rol oynamalarına yol açmıştır.

Brown (2016, s.244-247) tam da bu noktadan yola çıkarak sistemik değişimden dolayı aktör sayısındaki artışın çatışmanın karakterini de değiştirdiğini savunur. Bu değişimi değerlendiren Mumford, Hart'ın (2015) strateji tanımından yola çıkarak devletlerin dolaylı müdahalelerine vurgu yapar. Dolaylı müdahale dış aktörün çatışmanın tamamen dışında kalması gerektiği anlamına gelmez. Dış aktörler, vekillerin zayıfladığı ya da yetersiz kaldıkları durumlarda çatışmalara doğrudan müdahil olmak zorunda da kalabilirler. Böylesi durumlar çatışmayı vekalet savaşı olmaktan çıkarmaz. Suudi Arabistan öncülügünde 2015 yllında başlayan "Kararlılık Firtınası" operasyonu bu anlamda dikkat çekici bir örnektir.

Savaşın karakterindeki değişimi ve vekalet savaşlarındaki artışı Mumford (2013a) dört boyutta açıklamaktadır. Birincisi "teröre karşı savaş sendromu". ABD kendi ulusal çıkarları adına üçüncü ülkelerde terörle savaş yürütme ihtiyacı hissederken kamuoyu baskısından dolayı bu savaşı Vietnam sendromuna düşmeden yapmak zorundadır. Büyük çapta askeri birlikleri kullanmadan ve kapsamlı çatışmalara girmeden bunu sağlamanın en iyi formülü vekilleri kullanmaktır (Cragin, 2015). 2003 Irak’ın işgali sonrasında ABD’nin Sahva hareketlerine verdiği destek (Kadercan, 2018, s.240), Suriyede IşíD’e karşı yerel silahlı örgütlerin kullanımı, Afgan ordusunun ElKaide’ye karşı savaşması başlıca örneklerdir. Bu örnekler ortak bazı özelliklere sahiptir. Birincisi 
ABD’nin düşman olarak nitelediği örgütlere karşı savaş verilmiştir; ancak bu savaşı $A B D$ vekilleri üzerinden yürütmüştür. Ayrıca bu çatışmaların hepsi ABD topraklarının dışında gerçekleşmiştir.

İkincisi ise özel askeri şirketlerin dış kaynak olarak kullanılmış olmasıdır. 1989'dan itibaren devletler doğrudan bir askeri operasyon yürütmedikleri durumlarda kendi toprakları dışında operasyon yürüttükleri bölgelerdeki personel sayllarını düşürme trendine girmişlerdir. Bunun sonucunda ortaya çıkan güç boşluğu Afrika ve Balkanlarda iç savaşlara yol açmış ve bu boşluk özel sektörde gelişen askeri şirketler tarafından doldurulmuştur (Mumford, 2013a). Böylece devletler istedikleri bölgelere daha az maliyetle ve daha hızıı bir şekilde müdahale etme imkanı yakalamış oldular. Konvansiyonel savaşın maliyeti ve askeri bütçe kesintilerinin arttı̆̆ı dönemlerde bu formül oldukça işlevsel olmuştur (Mumford, 2017). 11 Eylül 2001 sonrası ABD’nin Afganistan ve Irak işgallerinin ortaya çıkardığı maliyet ve ABD içinde yarattığı tartışma bu durumun açık bir örneğidir. Ancak maliyet hesabı kendi içinde bir dilemmayı da içermektedir: Vekalet savaşlarında dış aktör ile yerel gücün maliyetleri karşılıklı olarak hafifletmesi ya da paylaşmaları (Mumford, 2013a) ve dış aktörün müdahale ederken vekilin tek başına üstesinden gelemeyeceği maliyeti hafifletmesi beklenir (Pfaff, 2017). Ancak bu norm çoğu zaman işlemez, çünkü dış aktörün en önemli hedeflerinden biri maliyeti azaltmaktır.

Üçüncüsü bilgisayar ve internet kullanımının artışı ile birlikte siber savaşların yeni bir savaş türü olarak ortaya çıkmasıdır. Bürokratik birimler ve hükümetlere bağlı kurumlara gerçekleştirilen saldırılar ülkeleri bu alanda daha fazla önlem almaya ve kapasitelerini genişletmeye yöneltmiştir. Buna paralel olarak NATO başta olmak üzere milli ordular ve istihbarat teşkilatlarının siber saldırılara karşı koyma ve karşı siber saldırı birimleri de daha fazla önlem almaya ve daha yüksek bütçeler kullanmaya yönelmişlerdir (Robinson, 2017). Firsat/maliyet hesabına göre yapılan bir araştırmada, gittikçe artan harcamaların siber risk unsurlarının stabil tutabildiğini ve fakat bu durumun önemli kazanımlar getirdiğini iddia etmektedir (Kempe ve Reyes, 2018). Dördüncüsü de, Çin'in yeni bir süper güç olarak küresel siyaset sahnesinde yükselmesinin ABD’nin ekonomik alandaki çıkarlarını etkilemesidir. Çin’in yükselişini durdurmak için nükleer ya da konvansiyonel güç kullanma tercih edilmeyeceğine göre dolaylı yollara başvurmak kaçınılmaz olmaktadır (Mumford, 2013a).

$\mathrm{Bu}$ tartışmalara dayanarak vekalet savaşının dönüşümüne dair şu analizi yapmak mümkündür: Vekalet savaşı Soğuk Savaş döneminde dolaylı bir strateji ya da ABD ile SSCB’nin üçüncü bir ülke üzerindeki güç mücadelesini tanımlamak üzere kullanılırken, Soğuk Savaş sonrasında daha çok yerel aktörler üzerinden üçüncü bir ülkede etkin olma ya da düşmanla mücadele etme yöntemi olmuştur. Bu mücadele yerel aktörler (vekiller) arasında sıcak bir çatışma şeklinde yürürken destekçileri konumundaki güçler ise ancak zorunlu olduğunda bu çatı̧̧malara dahil olmaktadır. Sonuç olarak vekalet savaşının içerdiği unsurları şu şekilde özetlemek mümkündür: dış aktörler, üçüncü bir ülke, bu ülkenin yerel güçleri, dış aktör-yerel güç iş birliği ve karşılıklı çıar. Bu unsurların bileşiminden vekalet savaşları çeşitli formları ile karşımıza çıkabilmektedirler. 


\section{Ortadoğu'da Vekalet Savaşları}

Yukarda zikredilen sebeplerin tümü Ortadoğu'da yaşanan vekalet savaşlarını açıklamak için geçerlidir. Arap isyanları sonrasında iktidar mücadelelerinin çatışmalı bir vekalet savaşına dönüşmesine neden olan temel unsur ise siyasi otoritelerin çökmesi ve yerel aktörlerin uluslararası güçlerle yakaladıkları işbirliği fırsatlarıdır. Suriye, Libya ve Yemen'de isyanlar dolayısıyla liderlerin iktidardan çekilmesi, öldürülmesi ya da otoritelerini kaybetmeleri sonucunda oluşan güç boşluğunun hızlıca doldurulamamış olması yeni bir iktidar mücadelesine zemin hazırlamıştır. Bunun temel sebebi ülkelerdeki kurumsallaşma düzeyinin çok düşük olması dolayısıyla siyasi iktidarın devrildiği yerde boşluk oluşması ve $\mathrm{ABD}$ başta olmak üzere bir çok uluslararası ve bölgesel aktörün bu ülkelerdeki iktidar mücadelesine dahil olmasıdır.

Ortadoğu'da yoğun bir şekilde devam etmekte olan vekalet savaşlarının tipik ve ilk örneği ABD’nin 2003'te Irak'ı işgal etmesiyle ortaya çıkmıştır. İsgal sonrasında Irak, ABD ile İran’n bir mücadele ve çatışma sahnesine dönüşmüştür. Gerek işgal sırasında gerekse sonrasında ABD'yi sınırlamak ve Irak’ta daha etkin olmak amacıyla İran, başta Şii milisler olmak üzere bir çok yerel aktörle işbirliği yapmıştır.

Siyasal değişim talebi ile başlayan Arap isyanlarının sıcak çatışmaya dönüşmesi bölgede yeni bir dönemin kapısını aralamıştır. Devrimsel süreçlerin sıcak çatışmalara ve iç savaşa dönüşmesi olağan bir süreç olarak kabul edilir. Hatta iç savaşın tarafları dış aktörlerden yardım da alabilir (Goldstone, 2011). Ancak vekalet savaşlarında dış aktörle yerel güç arasındaki ilişki yardımlaşmayı aşmaktadır. Vekalet savaşlarında vekil ile dış aktör arasında karşılıklı çıkar söz konusu olmakla birlikte vekil, dış aktöre bağımlı olmakta ve ortak amaçlar için savaşır durumdadır.

Arap isyanlarından sonra ortaya çıkan vekalet savaşları, dış güçlerin üçüncü bir ülkedeki çatışmaları şeklinde değil, destekledikleri aktörlerle işbirliği yaparak kendi etkinlik alanlarını genişletme amacıyla girdikleri çatışma süreçleri olarak devam etmektedir. Bu durum Hughes'in (2014) "bir devletin bir başka ülkede ortak bir düşmana karşı yerel bir aktörle kurduğu ortaklık aracilığıyla girdiği çatışma" ve Mumford'un (2013b, 25) ile "A devletinin kendi hedefleri için B devletinde bir vekil aracılığıyla dolaylı angajmanlarla operasyonlar yürütmesi” olarak tanımladığı vekalet savaşına karşlık gelmektedir. Vekil hükümetin kendisi, hükümete bağlı bir organ ya da devlet dışı bir aktör olabilir (Mumford 2013b, 40).

$\mathrm{Bu}$ anlamıyla vekalet savaşları bugün bir çok ülkede devam etmektedir. Suriye, Yemen ve Libya akla gelen ilk örneklerdir. Suriye'de İran ile Hizbullah ve diğer Şii milisler arasındaki ilişki; ABD ile YPG’nin kurduğu işbirliği; Türkiye ile bazı muhalif grupların Suriyede birlikte hareket etmesi, vekalet savaşlarında uluslararası güç ile yerel aktör arasındaki ilişkiye dair açık örnekleridir. Libya’da Fransa, Mısır ve Rusya’nın Halife Hafter'in öncülük ettiği gruba sağladığı destek; Yemen'de ise Suudi Arabistan’’n yerel hükümet güçleri ile bazı aşiretlerle kurduğu işbirliği ile İran’ın Husiler'in etkisi altındaki Ensarullah hareketi üzerinden ülkedeki güç mücadelesine dahil oldukları açıktır. Yerel aktörlerle dış destekçileri arasında kimi zaman ideolojik örtüşme söz konusu iken, kimi zaman ise zıt ideolojik görüşlere sahip aktörler arasında bir işbirliği söz 
konusu olabilmektedir. ABD ile YPG zit ideolojileri temsil ederken, Yemen'de ise vekillerle diş destekçileri arasında mezhepsel ve ideolojik bir örtüşme söz konusudur.

\section{Yemen'de Vekalet Savaşının Aktörleri ve Çatışma Süreci ${ }^{1}$}

İran ile Suudi Arabistan arasında bir çok alanda devam edegelen mücadele Yemen'e de yansımıştır. 1979 İran devriminden sonra İran, Suudi Arabistan’ın müttefiklerinden biri olan Yemen yönetimi ile çeşitli sorunlar yaşamış ve Husiler’le yakın ilişkiler kurmaya başlamıştır. Husiler bu tarihlerden itibaren hem Yemen yönetimi hem de Suudi Arabistan için bir güvenlik sorunu olarak görülmüştür. 2004-2010 yılları arasında Suudi Arabistan’ın Salih'e bağlı güvenlik güçlerinin Husiler'e karşı altı kez operasyon düzenlemesi (Fraihat, 2016, s.39) Husiler'in hem Salih iktidarı hem de Suudiler tarafından bir tehdit olarak algılandığını göstermektedir. Bu operasyonlar sırasında İran’ın da Husiler’e silah yardımı başta olmak üzere çeşitli alanlarda destek vermiş olması Yemen'de halen devam etmekte olan vekalet savaşının başlangıcı sayılabilir. Arap isyanlarından önce 2009 yılındaki operasyon Husiler’in Sa’da ve Amran kentlerinde okul, hastane ve güvenlik merkezlerinin kontrolünü ele geçirmeleri üzerine düzenlenmiştir (Zimmerman ve Hrnisch, 2018). Çatışmaların 2010 yılında sona ermesinin ardından 2011'de isyanların başlaması ile bu vekalet savaşı özellikle 2014 yılından itibaren derinleşmiş ve günümüzde de devam etmektedir.

Ocak 2011'de Yemen'de başlayan ayaklanmalar Ali Abdullah Salih yönetimince bastırılmak istendi. 2011 Ocak ayında Sanaa Üniversitesinde başlayan gösteriler kısa süre içinde Taiz, Aden gibi büyük şehirlere sıçradı ve kitlesel bir niteliğe büründü. Salih protestoları yatıştırmak için çeşitli reform vaatlerinde bulundu (Green, 2011) ancak protestolar büyüyerek devam etti. Ülkenin önde gelen din adamları ve aşiret liderlerinin de devrime destek verdiklerini açıklamaları (Aljazeera News, 2011) Salih'in meşruiyetinin aşındığı ve iktidarı bir arada tutmakta zorlandığına işaret etmekteydi. Bu durum aynı zamanda 1990 yılından beri Salih'in toplumsal yapıyı içerecek şekilde kurumsal düzeyde bir iktidar kuramadığının da göstergesiydi (Blumi, 2018, s.144-145). 18 Mart’ta yaklaşı 50 göstericinin ölümü ile sonuçlanan müdahale sonrasında General Ali Muhsin "protestocuların safına geçtiğini” duyurdu (BBC, 2011). Bu durum artık protestoların daha yoğun çatışmalara döneceği anlamına gelmekteydi.

Çatışmalar 2011 yılının sonuna kadar çeşitli düzeylerde devam etti. ABD ve Suudi Arabistan’ın KİK üyesi ülkelerle birlikte hazırladığı geçiş süreci şartlarını Salih'in 2011 yılının sonunda kabul etmesiyle çatışmalar donduruldu. Birleşmiş Milletler Güvenlik Konseyi’nin (BMGK) 2012'de aldı̆̆ 1 2051 no’lu kararı gereğince geniş bir uluslararası gözlemci heyetinin katılımı ile UDK (Fraihat, 2016, s.79-86) oluşturuldu. Bu çerçevede BMGK tüm taraflara şiddet kullanımından kaçınması ve müzakerelere yoğunlaşmaları çağrısını yaparken, Arap Yarımadası El-Kaidesi ile mücadelenin önünü açmaktaydı (UN Press, 2012). Konferansın amaçları geçiş sürecinin yönetilmesi, Yemen’in

1 Çalışmanın bundan sonraki kısımlarında yazar, 2015 yılında kendi adıyla yayınlanmış olan “'Devrim”den Askeri Müdahaleye Yemen" başlıklı rapordan kısmen yararlanmıştır. 
yeniden yapılandırılması ve temel sorunlarına barışçıl müzakereler yoluyla çözüm üretilmesi olarak özetlenebilir (Kurt, 2015, 11). Ocak 2014’e gelindiğinde Güney Yemen’in bağımsızlığını destekleyen ayrılıkçı gruplar ve Husiler UDK'dan çekildiklerini açıkladı. Ensarullah liderlerinden Muhammed El Bahti, UDK'dan çekilme gerekçesi olarak “federal bölgeler arasında ekonomik açıdan büyük farklılıkların olacağını” öne sürdü (Gulf News, 2014).

$\mathrm{Bu}$ tarihten itibaren iktidarı yeniden ele geçirmek isteyen Salih güçleri ile Husiler arasında bir ittifak söz konusu olmuştur. Al Zandani’ye göre (2015, s.104) Husilerin eski rejim güçleri ile ittifak yaparak çatışma yolunu seçmesi, UDK kararlarını akim bırakmakla kalmadı, aynı zamanda Yemen’in yeni bir çatışma dönemine girmesine zemin hazırladı (Abi-Habib, 2015). $\mathrm{Bu}$ andan itibaren Yemen krizi, yeni çatışma dinamiklerinin devreye girmesi ile açı bir şekilde vekalet savaşına dönüştü. Bu yeni çatışma dinamiği, - vekalet savaşı kavramının işaret ettiği üzere - yerel aktörlerin dış destekçileri ile işbirliği halinde birbirleri ile savaşma durumuna karşıllık gelmektedir. Çünkü bu tarihten itibaren İran ile Husiler arasındaki dayanışma artmış, Husiler kontrol alanlarını genişlettikçe İran da Yemen üzerinde daha etkin olmaya başlamıştır (Al Jazeera Center for Studies, (2015). Buna karşın Suudi Arabistan da destek verdiği Hadi güçlerinin zayıflaması karşısında KİK’e öncülük ederek doğrudan bir müdahalede bulunmuştur.

Yemen krizinin bir vekalet savaşına dönüşmesinin en önemli sebebi, vekalet savaşı kavramındaki unsurların kullanılması ile açıklanabilir. Deutsch'un(1980) ve Mumford'un(2013b), tanımlarından yola çıkarak vekalet savaşının üç ana unsuru, yerel aktörler, dış destekçileri ve bu iki unsur arasındaki karşılıklı çıkarlar üzerine kurulmuş işbirliğidir. Vekalet savaşları farklı ülkelerde farklı koşullarda ortaya çıabilmektedir. Afganistan'da Sovyet işgali ABD’nin krize müdahil olmasına yol açmış ve ABD yerel aktörlere destek vererek (Dooren, 2017) küresel rakibini yıpratma yoluna gitmiştir. 2003'te ABD’nin Saddam Hüseyin'i devirmesi oluşan ortamda ABD ile İran arasında Irak’ta etkinlik mücadelesi başlamış ve her iki taraf farklı aktörleri desteklemiştir.

Yemen'de de Salih yönetiminin iktidardan el çektirilmesi ile oluşan siyasi otorite boşluğunda yerel aktörler düzeyinde başlayan çatı̧̧malar Yemen'de etkinlik kurmak isteyen uluslararası aktörlere bir fırsat sunmuştur. UDK’nın başarısızlığa uğramasıyla birlikte Salih yeniden iktidar hesapları yapmaya başladı. Husiler bu kurulacak iktidarın bir parçası olmayı Hadi ve müttefikleri ise bu güçlerin -UDK'yı işlevsiz kılmaları dolayısıyla - dışarda tutma amacıyla hareket etti (Juneau, 2016, 647-648). Başka bir deyişle UDK’ya katılmış olan bu aktörlerin müzakere yoluyla amaçlarına ulaşamayacaklarına kanaat getirmeleri ülkedeki otorite eksikliğinin de etkisi ile bir çatı̧̧maya dönüşmüştür. Suudi Arabistna ile İran arasındaki ilişkilerin gergin seyri ve birbirlerine karşı etkinlik kurma mücadelesi çatışmayı kolaylaştırmış, derinleştirmiş ve bir vekalet savaşı boyutuna taşımıştır.

Yemen'deki vekalet savaşının bölgesel aktörleri Suudi Arabistan öncülüğündeki Körfez ittifakı ve İran'dır. Bu iki aktör 1979 yılından beri birbirlerine karşı konumlanmışlardır. Bu durum, her bir devleti diğerinin rakibi olarak kabul eden klasik uluslararası ilişkiler yorumunu aşmaktadır. Bu konumlanma, İran ve Suudi Arabistan’ın sürekli bir şekilde mücadele halinde olmalarına ve 
birbirlerine karşı ideolojik, mezhepsel, sert/yumuşak güç unsurlarını kullanmalarına yol açmıştır. Yemen de iki aktör arasındaki mücadele alanlarından birisi olmuştur. Suudi Arabistan on yılar boyunca Salih yönetimi ile işbirliği kurarken, İran 1979 devriminden sonra Zeydi koluna mensup Husilerle ilişkisini geliştirmiştir. Salih iktidarı sonrasında BM girişimine rağmen Husiler ile Hadi hükümetine bağlı güçlerin anlaşma yerine çatışmayı tercih etmeleri, işbirliği halindeki İran ile Suudi Arabistan’ın da bu çatışmaya dahil olmalarına ve Yemen üzerindeki mücadeleleri için bir araç olarak kullanmalarına yol açmıştır. Sonuçta Suudi Arabistan destekli Hadi güçleri ile İran destekli Husiler’in öncülük ettiği Ensarullah Hareketi ve işbirliği yaptığı bir takım aşiretlerden oluşan iki blok ortaya çıkmış ve vekalet savaşının taraflarını oluşturmuşlardır. Suudi Arabistan’ın amacı kendi vekillerini iktidarda tutmak ve Yemen üzerindeki kontrolünü devam ettirmektir. İran ise Husiler'in iktidarı ele geçirme çabasına destek vererek Suudi Arabistan'ın ülkedeki etkisini kırmayı amaçlamaktadır.

Bu iki blok birbirleri ile doğrudan mücadele halindedir. Üçüncü taraf olan ABD ise hükümetle koordinasyon halinde Arap Yarımadası El-Kaidesi’ne karşı askeri operasyonlar yürütmektedir. Bu operasyonlar birbirleri ile çatışma halindeki bloklarla doğrudan ilgili değildir. Ancak Yemen'deki çatışma dinamiklerinin bir parçası olması ve Trump yönetiminin Suud lehine İran’ı sınırlandırma söyleminin Yemen'deki vekalet savaşını etkileyebilecek olması dolayısıyla bu çalışmaya dahil edilmiştir. Sonraki her bir bölümde Yemen'deki vekalet savaşının nasıl ilerlediği ve uluslararası / bölgesel aktörler ile yerel aktörlerin attıkları adımlar bu çerçeve bağlamında incelenecektir.

\section{Suudi Arabistan ve Yemen Krizi}

Suudi Arabistan’ın Yemen'le ilişkilerinin uzun bir tarihi vardır. Başka bir deyişle bu ülke üzerindeki etkisi ve jeopolitik hesapları Arap İsyanları ile birlikte ortaya çıkmış değildir. Ali Abdullah Salih dönemi boyunca Yemen, Suudi Arabistan’ın en yakın müttefiklerinden biri olagelmiştir. Suudi Arabistan için Yemen'in istikrarlı olması ve sınırındaki Husileri kontrol altında tutması oldukça önemli önceliklerdir. Ayrıca Mendeb Boğazının güvenliği ve ticari geçişlerin güvenli bir şekilde devam etmesi bir diğer önemli faktördür. Dolayısıyla Salih rejiminin devamlılığı ile ülkenin istikrarının devamını temin etmek amacıyla Suudi Arabistan Yemen'de hem askeri alanda etkinlik sahibi olmuş hem de zaman zaman ekonomik yardım sağlamıştır (Pradhan, 2017, s.7071). 2011'de Salih yönetimine karşı protestolar başladığında Suudi Arabistan Yemen üzerindeki etkisini kaybetmemek amacıyla krizin seyrine göre farklı stratejileri devreye sokmuştur. Bu anlamda ilk stratejisi Salih'in iktidarını koruyamaması durumunda geçiş sürecini kendi kontrolü altında tutmaktı. Ancak 2014'ten itibaren Husiler'in siyasi mekanizmayı ele geçirmeleri karşısında Hadi’ye bağlı güçlerle işbirliği halinde askeri operasyon düzenlemiştir.

Salih yönetimine karşı protestolar başlayınca Suudi Arabistan değişim sürecinde inisiyatifi bırakmamak amacıyla KİK’i devreye sokarak ağırlığını koymaya başladı. Suudi Arabistan’ın temel amacı istikrarın yeniden sağlanması ve ideolojisi ve vizyonu açısından - Müslüman Kardeşler ile benzerlik taşıdığı için 'İhvan’n Yemen kolu’ olarak değerlendirilen (Lewis, 2015, s.21-22) - Islah 
Partisi ya da İran müttefiği olarak gördüğü Husiler’in ciddi bir etkinlik sahibi olmadığı yeni bir iktidar oluşturmaktı. Salih’e dokunulmazlık sağlanması, 'eski devlet başkanı' statüsü ile korunacak olması ve Genel Kongre’nin geçiş hükümetinde bir aktör olması da (NTV Haber, 2011) bu amaca matuftu. Salih’in yardımcısı Hadi’nin, ilk seçimlerde Cumhurbaşkanı adayı olarak belirlenmesi de aynı bağlamda değerlendirilebilir.

Ancak Husiler'in Ocak 2014'te UDK'dan çekilerek Sa'da kentinden başlamak üzere adım adım Yemen'i kontrol etmeleri karşısında Suudi Arabistan yeni bir strateji belirlemek zorunda kalmıştır. Çünkü 2014 Eylül'ünde başkent Sanaa’ya ulaşan Husi güçleri, 22 Ocak 2015’te Cumhurbaşkanı Hadi'yi istifaya zorlamış ve 6 Şubat'ta da Meclisi de feshetmişlerdir. Bu gelişmeleri KİK bir darbe olarak yorumlamış fakat Husiler bu görüşe karşı çıkmıştır (MEPC, 2015). Başkent Sanaảın Husiler tarafından kontrol edilmesi ve İran’n oynadığı rolü Ottaway, (2015) Suudi Arabistan’n, "İran ve müttefikleri tarafından çevrelenmenin son halkası" olarak yorumlamıştır. Suudi Arabistan öncülügündeki Körfez ülkeleri de bu durumu bir güvenlik meselesi olarak değerlendirmiş ve askeri müdahale seçeneğini öncelemişlerdir.

Yemen Cumhurbaşkanı Hadi’nin BM nezdindeki girişimi, Suudi Arabistan için bu bağlamda bir firsat doğurmuştur (Kurt, 2017). Hadi 25 Mart 2015’te BM’ye bir mektup yazarak Güvenlik Konseyinden Yemen’de Husilerin ilerleyişini durdurmaya "gönüllü ülkelerin" askeri müdahalesine yetki veren bir karar almasını istedi. Hadi, ayrıca Körfez ülkelerinden "Yemen'in güvenlik açısından yardıma ihtiyaç duyduğunu, Yemen'deki Husi darbesine karşı BM’nin 51. maddesi gereğince askeri müdahale dahil her türlü adımı atmalarını" istemiştir (Hadi, 2015, s.3-5). KİK bu çağrıyı gerekçe göstererek Suudi Arabistan öncülüğünde 26 Mart 2015’te Kararlılık Fırtınası adı altında askeri bir müdahale başlatmıştır (The Embassy of Kingdom of Saudi Arabia, 2015). Operasyonun temel amacı Husiler' in bertaraf edilmesi ve Hadi iktidarının yeniden tesis edilmesiydi (Darwich, 2018, 125). BAE, Katar, Bahreyn, Ürdün, Sudan, Kuveyt, Misır ve Fas operasyona destek verdiğini açıklamıştır. ${ }^{2} \mathrm{Bu}$ operasyona zemin hazırlayan üç ana neden ise, ifade edildiği üzere Husiler'in Yemen'in kontrolünü büyük ölçüde ele geçirmeleri, İran’ın Yemen'de daha etkin bir konuma gelmesi ve ABD’nin bu duruma yönelik bir adım atmamasıdır (Al Jazeera Center for Studies, 2015, 4).

Suudi Arabistan/BAE, destekledikleri yerel kuvvetler yetersiz kaldıkça yabancı savaşçı kullanma yoluna gitmişlerdir (Hager ve Mazzetti, 2015). Bu durum bir yandan kapasite artırımı olarak yorumlanabilecekken özellikle koordinasyon açısından çeşitli dezavantajlar da yaratmaktadır. Zaman zaman Suudi Arabistan/BAE’nin desteklediği gruplar arasında çatışmaya varan koordinasyonsuzluk gözlemlenmiştir. Güneyli ayrılıkçılar ile Hadi hükümetine bağlı güçler arasında (Mukhashaf ve Kalin, 2018) ve Hadi güçleri ile saf değiştiren Salih taraftarları arasında patlak veren çatışmalar (BBC, 2017) bu durumun örnekleridir.

2 Haziran 2017'de Körfez ülkeleri arasında patlak veren kriz sonrasında Katar operasyondan çıkarıldı (Timetürk, 2017) 
Yaklaşık dört yıldır devam etmesine rağmen bu müdahaleden istenen sonuç elde edilememiştir. Bunun temel sebebi operasyonun asimetrik bir karaktere sahip olmasıdır. Suudi Arabistan/BAE hava gücü ve düzenli birliklerle Husiler’i geriletmeye çalışırken, Husiler ise gerilla taktiklerinden düzenli saldırılara, alan savunmasından vur-kaç saldırılara kadar farklı taktikleri kullanmışlardır. Ayrıca askeri müdahaleyi Husiler, yabancı işgalci güç olarak tanımlamayarak (Hilterman and Alley, 2017) söylemsel düzeyde üstünlük elde etmek amacıyla sorunsallaştırmışlardır,

\section{İran ve Yemen Krizi}

İran’n Yemen'e olan ilgisi 1960'lara kadar geri gitmektedir. Ancak bu ilgi, Mısır’n desteklediği Cumhuriyetçiler ile Suudi Arabistan’’n desteklediği Monarşi yanlıları arasında yaşanan iç savaşı Cumhuriyetçilerin kazanması sonucunda 1960'ların sonundan itibaren zayıflamıştır. 198088 İran-Irak savaşı sırasında Yemen yönetiminin Irak’a destek vermesi de iki ülke yönetimleri arasındaki gerginlikleri artırmıştır (El Qadhi, 2017, 24-26). İran’’n Yemen siyaseti üzerinde etki kurma girişimleri ise 1979 İran devriminden sonra yoğunlaşmıştır. Bu amaçla İran özellikle Zeydi koluna mensup bir aşiret olan Husiler'le yoğun bir ilişki kurmuştur. Zeydilik Şiiliğin bir yorumu olmakla birlikte bu ilişkinin mezhepsel yönü tartışmalıdır (Hilterman and Alley, 2017). Çünkü Yemen nüfusunun yüzde 30-35'lik bir kısmını oluşturan Zeydilerin tümü İran’la aynı düzeyde ilişki kurmamışlardır. Bu durum iki temel sebeple açıklanabilir. Birincisi Şiiliğin bir yorumu olan Zeydilik ile İran’n benimsediği On iki imam Şiiliği ile arasındaki doktriner ayrışmadır (Büyükkara, 2011; Rieder, 2017). İkinci sebep ise Yemen Zeydilerinin organizasyonel düzeyde kimlik siyaseti yürütmemiş olmalarıdır. Doktriner ve pratik düzeydeki bu iki sebep İran’n Zeydilerin bütünü üzerinde bir etki sahibi olmasını zorlaştırmıştır.

Buna karşın Zeydiliğe mensup Husi aşiretleri bir istisna oluşturmuşlardır. Zira Husiler'in 1979 devriminden sonra İran ile yakın ilişki kurdukları bilinmektedir. Bedreddin El-Husi'nin vaazlarında Humeyni'ye yönelik övgüleri, 1986 ziyaretinden sonra İran'da eğitim alan Husilerin sayısındaki artış ve 1994'ten sonra Hüseyin Husi'nin İran'da uzun süre kalması iki aktör arasındaki yakınlaşmanın işaretleri olarak yorumlanmıştır (Büyükkara, 2011; Arı, 2015). Bu yakınlaşmanın, 1962'de Zeydi iktidarının devrilmesinden sonra Sünni öğretinin Zeydileri dönüştürmeye başlamasına bir tepki olarak doğduğu ifade edilmektedir. Husiler' in organize bir yapı kazanmaları da bu yıllarda söz konusu olmuş ve 1990 yılından itibaren 'İnançlı Gençlik Forumu’ adı altında çeşitli faaliyetler göstermişlerdir. Bu yapı 2000 'lerin başından itibaren ise daha siyasi ve askeri bir yapıya evrilmeye başlamıştır (Albahesh, 2018).

2004 yılında merkezi hükümet güçleri ile Husiler arasındaki çatışmalarda İran yapımı silahlara rastlanmış olması İran'la aralarındaki işbirliğinin yalnızca eğitim alanında kalmadığına yönelik bir işaret olarak değerlendirilmiştir (El Alim, 2015; Ahmad, 2018). Husiler'in bu silahları karaborsadan ve Yemen ordusundan edindikleri iddialarına karşılık (Juneau, 2016, 656), Suudi Arabistan ve ittifak halindeki eski Yemen yönetimi mütemadiyen Husiler'i İran’n vekili olmakla suçlamış (Juneau, 2016, 652) ve İran’ı da ülkede istikrarsızlık yaratmaya çalışmakla suçlamışlardır. 
Özellikle Seyyid Hüseyin Bedreddin El Husi’nin liderliğinde 2004'te başlayan Husi isyanından beri İran, isyancıların destek aldığı olağan şüpheli ülkelerden birisi olarak görülmüştür (Sinkaya, 2015, s.61).

2011'de isyanlar başladıktan sonra Husiler yoğun bir nüfusa sahip oldukları Sada kentinde merkezi yönetimden bağımsız hareket etmeye başlamışlardır. Vali atama, yerel hizmetlerin karşılanması ve daha önemlisi vergi toplama gibi etkinliklerde bulunmaları bu bölgede yönetimi üstlendikleri şeklinde yorumlanmıştır (International Crisis Group, 2014). Suud öncülüğündeki Körrfez insiyatifinin bir parçası olmamasına rağmen İranı̀n Husiler’e desteği söz konusu olmuştur (Feierstein, 2018). Bu süreçte medyada yer bulan İranın Husilere silah yardımında bulunduğuna ilişkin iddialar Husiler'in kendi amaçlarına ulaşmak için İran'la kurdukları ilişkinin mahiyetine ilişkin önemli bir ipucudur. 2013 yılında Yemen yönetimi, Husilere silah taşıyan 'Cihan 1' isimli bir geminin durdurulduğunu açıklamıştır (Hürriyet, 2015). Bu iddialar ABD hükümet sözcüleri tarafından da desteklenmiştir (White House Press Office, 2013). İran yönetimi bu iddiaları reddetse de, Yemen yönetimi ve müttefiklerinin Husi-İran ilişkilerini nasıl değerlendirdiğini göstermesi açısından önemlidir. Husiler ise İran'la ilişkilerinin yalnızca yardım ve destek kapsamında değerlendirilmesi gerektiğini İran'dan talimat ya da emir almadıklarını ifade etmişlerdir (Salisburry, 2015). Bu açıklama İran ile Husiler arasındaki ilişkiyi doğrulamış olması açısından önemlidir.

Bu süreçte İran’ın takındığı tavır ve İranlı yetkililerin kullandıkları ifadeler de Husiler'le sahip oldukları ilişkinin boyutlarını açığa vurmuştur. İran dini lideri Ali Hamaney’e yakınlığıyla bilinen Tahran milletvekili Ali Rıza Zakai’nin, Yemen’in başkenti Sanaảnın Husiler tarafından kontrol edilmesine yönelik yorumu dikkat çekicidir. Zekai, "Üç Arap ülkesi İslam devrimine bağlanarak İran’n kontrolüne girmiştir. Sanaa, İran devrimine katılan dördüncü Arap başkenti oldu" (Ez Zeatira, 2014). Benzer şekilde bu ilişkinin boyutlarına işaret eden bir açıklama da İran dini lideri Ayetullah Ali Hamaney'in Uluslararası İlişkiler Danışmanı Ali Ekber Velayetiden geldi. Velayeti’nin sözleri Husiler'in Yemen yönetimini ele geçirmeye dair isteklerine işaret etmektedir. "Yemen devrim lideri Abdulmelik El Husi tedbirli ve cesaretli biri. Hareketi ve değerli dünya görüşüyle devrimi yönetmesinden memnunuz. Hizbullah’n Lübnan'da üstlendiği rolü, Ensarullah’in Yemen'de üstlenmesini umut ediyorum" (NTV Haber 2015). İran'll yetkililerin sarf ettiği bu sözler İran’n Yemen'de Husilerle yaptıkları işbirliğine ve dolayısıyla Yemen'deki çatışmanın bir vekalet savaşı olarak devam ettiğini göstermektedir.

İran ayrıca, 2015 yllının başında yönetime el koyan Husiler'i meşru bir iktidar olarak görmüş ve bir dizi anlaşma imzalama yoluna gitmiştir. Petrol, elektirik, havacılık ve deniz taşımacilığ gibi bir çok alanda stratejik değeri olan ekonomik anlaşmalar imzalanmıştır. Ayrıca üstyapıyı çalışmaları için kredi vermiştir (Al-Qadhi, 2017, 27). Bu adımlar İran’n Husi yönetiminin 
ülkedeki meşruiyetini sağlamaya ve uluslararası tanınırlığını genişletmeye matuf bir çaba olarak değerlendirilebilir.

Suud öncülüğündeki 'Kararlılık Fırtınası' operasyonun başlamasıyla birlikte İran tepkisini diplomatik alanda göstermiştir. Dışişleri Bakanı Cevad Zarif, BM’ye gönderdiği mektupta ateşkesi sağlamak ve Yemen krizinin çözümü için dört maddelik bir plan sunmuştur: Bu dört madde, Yemen'de ateşkes ilan edilmesi ve yabancı askeri saldırıların durdurulması, acil insani yardımın ulaştırılması, müzakere sürecinin tüm tarafları içerecek şekilde yeniden başlatılması ve tüm aktörlerin yer alacağı ulusal birlik hükümetinin kurulmasıdır (Charbonneau, 2015). Bu planın temel amacı Suud müdahalesini sona erdirmek ve Husiler'in kazanımlarını korumaktı. Ancak İran’ın bu girişimi ne operasyonu başlatan aktörler ne de uluslararası kamuoyu nezdinde herhangi bir karşılık bulmamıştır. İran’ın krizin hemen her safhasında attığı adımlar ve Suudi Arabistan ile müttefiklerini zayıflatmak için Husilere sağladığı destek Yemen'de yürüttügü vekalet savaşının bir işaretidir.

\section{$A B D$ ve Yemen Krizi}

ABD yönetiminin Yemen'e ilişkin iki önemli boyutta bir politika yürüttüğünü ifade etmek mümkündür. Birincisi Yemen'de Salih sonrası kendi aleyhine bir iktidar kurulmasının önüne geçmek; ikincisi de ülkedeki El-Kaide’ye bağlı gruplara karşı yürüttüğü operasyonları devam ettirmektir. Birinci amaca yönelik olarak ABD, 2011 yılında Suudi Arabistan yönetimi ile koordine halinde değişim sürecini yönetmek için bir çaba sarf etmiştir. Bu bağlamda ABD kendi çıkarlarını garanti altına alacak bir süreç yönetimi planlamıştır. Al Zandani’ye göre (2015, s.92) ABD’nin bu süreçteki temel kaygısı, Yemen yönetiminin İslamcı olarak nitelendirdiği grupların eline geçmesiydi.

ABD’nin ikinci hedefi ise Yemen'deki El-Kaide varlığıdır. Nitekim Yemen, ABD’nin El-Kaide’ye bağlı gruplara karşı operasyon yürüttüğü ülkelerin başında gelmektedir. Bu anlamda Barack Obama’nın küçük özel birlikler, özel askeri şirketler ve İHA'larla yürüttüğü operasyon 2009 yılından beri Yemen'de etkili bir şekilde devam etmektedir. Bu tarihten itibaren Yemen yönetimi ile başlayan işbirliği gittikçe artmıştır (Hill, 2017,s.238-253). Operasyonların önemli bir kısmı hava saldırısı şeklinde gerçekleşmiş ve büyük oranda İHA’lar aracılığıyla yapılmıştır. 2016 yılında iktidara gelen Donald Trump, Yemen ile ilgili "Somali ile birlikte düşmanların aktif olduğu yer" ifadelerini kullanmış ve Obama’nın uyguladığg stratejiyi devam ettirmiştir (Kube, Windrem, Arkin, 2018). Bu stratejinin yol açtı̆̆ sivil kayıplara rağmen artarak devam etmesi (New America, 2018) ABD’nin bu politikada ısrar ettiğine dair önemli bir göstergedir. 
Tablo 1: Yemen’de ABD’nin Havadan Gerçekleştirdiği Saldırıların Yıllara Göre Dağılımı

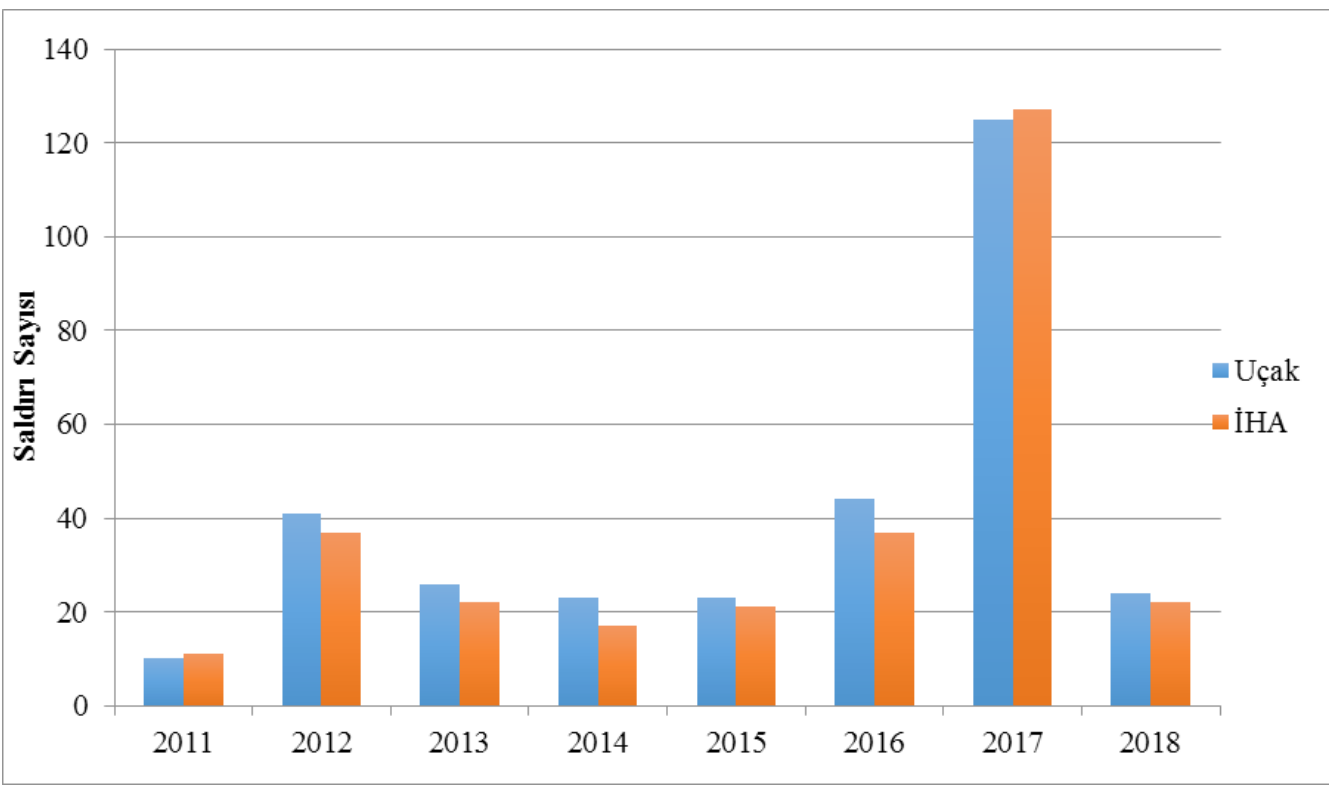

(Bu tablodaki veriler Statista 2018 a ve Statista 2018 b 'den elde edilmiştir)

Bu tablodaki saldırıların sayısında meydana gelen artış ABD’nin Yemen'deki krizin kendisini dikkate almadığı ve El-Kaide gruplarına karşı mücadeleye odaklandığına işaret etmektedir. Ayrıca Hadi'nin Cumhurbaşkanı seçilmesinden sonra ABD’nin, bir kısmı El Kaide ile mücadelede kullanılmak üzere, Yemen yönetimine sağladığı yardımlarda belirgin bir artış olmuştur (Sharp, 2015). ABD bir yandan kendi gündemine odaklanmışken müttefiki Suudi Arabistan’ın beklentilerini nasıl karşılayacağı bir başka önemli nokta olmuştur. Suudi Arabistan ve BAE’nin 'Kararlılık Fırtınası' ile başlattıkları müdahalenin temel amacı İran'ın Yemen'deki etki alanını sinırlandırmaktı. Obama döneminde ABD bu operasyona bir engel koymazken somut bir destek de vermemiştir. Trump’in iktidara geldikten sonra İran’ı sorunsallaştıran ve tehdit eden söylemini Suudi Arabistan ve müttefikleri memnuniyetle karşılamışlardır. Ancak Trump yönetimi de Yemen'deki krizi Suudi Arabistan ve BAE lehine değiştirecek somut bir adım atmamıştır.

'Kararlılık fırtınası' operasyonu başladığında birçok araştırmacı savaşın uzun sürmesi durumunda Suudi Arabistan’ın istikrarsızlaşacağınıve ABD’nin ancak bu noktada krize müdahale edebileceğini dile getirmişlerdir. Dolayısıyla ABD’nin, başta Suudi Arabistan olmak üzere petrol üreticisi KİK ülkelerinin istikrarına dikkat kesilmesi gerektiğini dile getirmişlerdir (Pollack, 2015). Bu yorum tersten okunduğunda Suudi Arabistan istikrarsızlaşana kadar ABD yönetiminin müdahale etmeyeceği sonucunu çıkarmak mümkündür. Trump’in da İran’ı daha fazla sıkıştırmak için Suudi Arabistan petrolüne ihtiyaç duyduğu bilinmektedir. İran'a ambargo uygulanırken petrol arzında her hangi bir aksamanın yaşanmaması gereklidir. Bu açıdan bakıldığında Suudi Arabistan’ın istikrarını devam ettirdiği sürece Trump yönetimi ile anlaştığı üzere (Amerika’nın Sesi, 2018) petrol arzını artırması beklenir. Suudi Arabistan’ın Yemen dolayısıyla henüz istikrar tehlikesi 
yaşamadığı dikkate alınırsa ABD’nin Suudi Arabistan/BAE lehine somut sonuçlar üretecek bir müdahalede bulunması zor görünmektedir.

Trump yönetiminin İran'la varılan nükleer anlaşmayı askıya aldıktan sonra tekrar masaya oturmak için İran’ın özellikle devlet dışı aktörlerle (ABD bu aktörlerin bir kısmını terör örgütü olarak tanımlamaktadır) olan ilişkiyi kesmeyi de şart koşmuştur. Bu bağlamda "Yemen'de Husiler’e verdiği desteği kesmesi” ( Pompeo, 2018) şartı açıkça dile getirilmiştir. Ancak ABD ElKaide’ye odaklanan stratejisini, doğrudan İran ve Husiler’i hedef alacak şekilde değiştirmemiştir.

\section{Sonuç}

İran ile Suudi Arabistan’ın Yemen üzerindeki güç mücadelesinin kökenleri 1970’lerin sonuna kadar geri gitmektedir. 2004-2010 yılları arasında Yemen'in kuzeyinde Husi güçleri ile Yemen yönetimi arasında yaşanan çatışmalar, Suudi Arabistan'ın bu çatışmalara doğrudan müdahale etmesi ve İran’n bu dönemdeki Husiler’e yönelik yardımı günümüzde devam etmekte olan vekalet savaşının başlangıcı sayılabilir. 2011 gösterileri ile birlikte bu vekalet savaşı derinleşmiş ve Yemen açısından önemli sonuçlar üretmiştir.

Ali Abdullah Salih'in kitlesel gösterilere yaklaşık on ay boyunca direndikten sonra KİK inisiyatifinde iktidardan çekilmeyi kabul etmesi, Yemen için yeni bir dönemin başlangıcı olarak kabul edilmiştir. Ancak bu yeni dönem beklendiği gibi demokratikleşme ve yeniden inşa sürecine evrilmeden iç savaşa dönüşmüştür. Bu iç savaşa uluslararası aktörlerin dahil olması ise krizin bir vekalet savaşına dönüşmesine neden olmuştur. Yemen'deki vekalet savaşının bölgesel tarafları İran, Suudi Arabistan, BAE ve diğer KİK ülkeleridir. Uluslararası aktör ise ABD'dir. Yerel aktörler ise meşru hükümet olarak görülen Cumhurbaşkanı Hadi ve emrindeki güçler, Husiler ve Yemen El-Kaidesi’dir. KİK ülkelerinin işbirliği yaptığı aktör Cumhurbaşkanı Hadi'dir. İran, Husiler'i desteklemekte, ABD ise El-Kaide’ye karşı askeri operasyonlar yürütmektedir.

Yemen'deki krizin vekalet savaşına evrilmesi Yemen, Ortadoğu bölgesi ve hatta küresel siyaset düzeyinde çeşitli sonuçlara yol açmıştır. Vekalet savaşlarının görüldügüü ülkelerde siyasibütünlügün yeniden sağlanması uzun bir zaman alabilmektedir. SSCB’nin 1989 yılında çekilmesine rağmen Afganistan’ın; 2003'ten beri Irak’ın siyasi yönetim açısından hala bütünlüğünü sağlayamamış olması çatışmanın farklı formlarda (etnik çatışma, terör saldırıları) devam etmesi bu açıdan önemli örneklerdir. Benzer bir durumun Yemen'de de yaşanma olasılı̆̆ yaklaşık altı yıldır devam etmesine rağmen çatışmaların bitmemiş olması, taraflardan birinin üstünlük sağlayamaması ve BM girişimlerine rağmen uzlaşmanın sağlanamamış olması ülkedeki sorunları daha kaotik bir düzeye taşımıştır.

Vekalet savaşının çok boyutlu ve çok aktörlü bir düzleme sahip olması çözümü de zorlaştırmaktadır. 2016 yılında Kuveyt'in arabuluculuğunda üç ay boyunca yürütülen müzakerelere rağmen bir sonuç elde edilememiştir. Yemen krizi boyunca dört BM Yemen özel temsilcisi görev almış ve fakat çatışmalar kesilmeden devam etmiştir. Bu yılın başında yeni temsilci olarak atanan Martin 
Griffiths'in ateşkesi sağlama ve kalıcı bir barış ortamı sağlamak için sergilediği çabalar da çok sınırlı bir sonuç üretmiştir. Uzun süren arabuluculuk müzakereleri sonrasında Aralık 2018'de hükümet yetkilileri ile Husi temsilcileri bir araya gelmiş ve ateşkes üzerinde bir anlaşmaya varmışlardır. Ancak bu ateşkes durumu yalnızca Hudeyde kenti için söz konusu olmuş kısa sürmüştür.

Bu uzun süreli kaotik çatı̧̧ma uzadıkça ortaya çıkan insani maliyet de büyümüştür. BM ve çeşitli uluslararası kuruluşların raporlarına göre Kasım 2017'ye kadar ölü sayısı beş bini aştı, yaralı sayısı ise kırk bine yaklaşmış ve bir milyondan fazla insan yer değiştirmek zorunda kalmıştır. Nüfusun \%75 (on sekiz milyon kişi) bir şekilde insani yardıma muhtaç duruma düşmüştür. Nüfusun \%60’1 (13 milyon kişi) açlık tehdidi ile karşı karşıya, \%56'sı (12 milyon kişi) ise sağlık kurumlarına erişememektedir. Sağlık kurumlarının yarısı zarar görmüş durumdadır. 8.4 milyon kişinin bir sonraki ögünü elde edip edemeyeceği kesin değildir. İki milyon çocuk yetersiz beslenmeden etkilenmiştir. Kamusal hizmetlerin yerine getirilememesi dolayısıyla şehirlerde çöp yı̆̆ınları birikmiştir. Altyapının işlevini kaybetmesi sonucunda bulaşıcı hastalıklar kitlesel düzeyde sağlık sorunlarına yol açmaktadır. Çatışmalardan etkilenmeyen tek bir ailenin bile kalmadığını ifade eden Kızılhaç Komitesi Başkanı Peter Maurer, Yemen'deki durumu "insan eliyle üretilmiş bir felaket” şeklinde tanımlamış ve durumun günden güne kötüleştiğini vurgulamıştır.

Yemen'deki vekalet savaşı aynı zamanda bölgesel güvenliği etkilemektedir. İran ile Suudi Arabistan arasındaki gergin ilişkiler Yemen'deki çatışmaya doğrudan yansımaktadır. Suudİran mücadelesinin farklı nedenlerden dolayı gerginleşmesi Yemen'deki çatışmanın seyrini de etkilemektedir. Yemen'deki yerel aktörler arasındaki çatışmanın alevlenmesi de İran-Suud mücadelesini gerginleştirebilmekte ve farklı yerlerde yeni hesaplaşmalara yol açabilir. Bu kısır döngüden çıkış ya bir tarafın üstünlüğünü kabul ettirmesi, ya da İran-Suud arasında bir uzlaşıya varılması ile mümkün olabilir.

İan ile Suudi Arabistan’ın Yemen'deki mücadelesinin küresel boyutu ilgilendiren tarafı ise Mendeb boğazının kapanma olasıllı̆ı ve ABD’nin tavrına bağlı olarak şekillenecektir. Mendeb boğazı Körfez ülkelerinden Avrupa’ya gerçekleşen ham petrol sevkiyatında önemli bir ticaret yoludur. Zaman zaman boğazdan geçen gemilere gerçekleşen saldırılar bu ticareti aksatabilmektedir. ABD’nin İran’’ sınırlandırma söyleminin bir stratejiye dönüşmesi durumunda ise ABD’nin Yemen’e müdahalesi El-Kaide karşıtı operasyonlarla sınırlı kalmayacaktır. Trump’nn iktidara gelmesiyle Suudi Arabistan ve BAE böylesi bir politika değişikliği için ABD yönetimine baskı yapmaktadır. Trump’ı İran’ sorunsallaştırmaya dair söylemi, nükleer anlaşmayı askıya alması ve ekonomik yaptırımları uygulamaya sokmuş olması ABD’nin İran politikasına dair olası senaryolara işaret etmektedir. Ancak Trump’n İran'la yeniden müzakere etmek için Husiler’i destekleme politikasından vazgeçme şartına rağmen Yemen'deki İran etkinliğini kırmaya dönük doğrudan bir müdahalesinden söz etmek oldukça zordur. Ekonomik yaptırımların İran’’n ülke dışındaki etkinlikleri azaltmaya sevk edip etmeyeceği de henüz belirsizdir. 


\section{Kaynakça}

Abi-Habib, M. (2015). "Yemen’s Ousted President Saleh Helps Propel Houthi Rebel Advance”, Wall Street Journal, 10.04.2015, https://www.wsj.com/articles/yemens-ousted-president-saleh-helpspropel-houthi-rebel-advance-142.870.4009

Ahmad, A. (2018). “'Clear evidence of Iranian involvement in Yemen”', June 19, 2018, https://gulfnews.com/ uae/government/clear-evidence-of-iranian-involvement-in-yemen-1.2239333

Albahesh, A. (2018). “The Houthi Movement in Yemen: From Insurgency to Military Coup, 2004-2014”, October 22, 2018, https://medium.com/@drabdoalbahesh/the-houthi-movement-in-yemen-frominsurgency-to-military-coup-2004-2010-6756fbfa410b

Al Zandani, Ahmed A. (2015). "Yemen’s Question: From the Struggle for Freedom to the Struggle for Survival”, Türkiye Ortadoğu Çalışmaları Dergisi, Vol: 2, No: 2, 89-108.

Aljazeera (2011). “Top army commanders defect in Yemen”, 21 Mart 2011, https://www.aljazeera.com/news/ middleeast/2011/03/201.132.0180579476.html

Al Jazeera Center for Studies, (2015). Operation Decisive Storm: Reshuffling Regional Order, http://studies. aljazeera.net/mritems/Documents/2015/4/7/201.547.83015689734Operation\%20Decisive\%20 Storm.pdf

Alptekin H. (2017) "A theory of ethnic violence: ethnic incorporation and ethno-political mobilization in Bulgaria and Cyprus", Ethnic and Racial Studies, 40 (15), 2672-2790.

Amerikanın Sesi (2018). “Trump: 'Kral Salman Petrol Üretimini Arttırmayı Kabul Etti', 30.06.2018, https://www.amerikaninsesi.com/a/trump-kral-salman-petrol _ \%C3\%BCretimini-artt\%C4\%B1rmay\%C4\%B1-kabul-etti/4461472.html

Arı, T. (2015). "Yemen’de Arap Baharından Husi Darbesine: Bir Demokrasi Denemesinden Başarısız Devlete mi?", SDE Bakış, No:8, 1-10.

B. Hager E. and Mazzetti M. (2015). "Emirates Secretly Sends Colombian Mercenaries to Yemen Fight", Newyork Times, 25 Kasim 2015, https://www.nytimes.com/2015/11/26/world/middleeast/emiratessecretly-sends-colombian-mercenaries-to-fight-in-yemen.html

BBC. (2011). “Top Yemeni general, Ali Mohsen, backs opposition”, 21 March 2011, https://www.bbc.com/ news/world-middle-east-12804552

BBC. (2017). "Yemen war: Fighting breaks out among allied rebels", 30 Kasim 2017,

https://www.bbc.com/news/world-middle-east-42179313

Blumi, I. (2018). Destroying Yemen What Chaos in Arabia Tells Us About The World, O a k l a n d : University of California Press.

Brown,,S. (2015). "Purposes and pitfalls of war by proxy: A systemic analysis", Small Wars \& Insurgiencies, Vol.27, No.2, 243-257.

Büyükkara, M.A. (2011). “Sosyal, Siyasi ve Dini Yönleriyle Yemen Husi Hareketi”, Divan, c.16, 115-151.

Charbonneau, L. (2015). "Iran submits four-point Yemen peace plan to United Nations", Reuters, April, 17 2015, https://www.reuters.com/article/us-yemen-security-iran/iran-submits-four-point-yemenpeace-plan-to-united-nations-idUSKBN0N823.820.150417

Cragin, K. (2015). "Semi-Proxy Wars and U.S. Counterterrorism Strategy”, Studies in Conflict \& Terrorism, $38: 5,311-327$.

Darwich, M. (2018). “The Saudi Intervention in Yemen: Struggling for Status”, Insight Turkey, Spring 2018, Vol.20, No.2, pp. 125-142. 
Deutsch, K. W. (1980). "External Involvement in Internal War", in Harry Eckstein (Eds), Internal War: Problems and Approaches, West Port: Praeger.

Dooren, van K. (2017). The Method And Consequences Of The Global Proxy War In Afghanıstan, 19791989, Master Thesis, International Relations, Leiden University

Eker, S. (2015). “Savaş Olgusunun Dönüşümü: Yeni Savaşlar ve Suriye Krizi Örneği”, Türkiye Ortadoğu Çalışmaları Dergisi, Cilt: 2, Sayı: 1, 2015, 31-66.

El Alim, E. (2015). "Husi-İran ilişkisi: Mezhep kılıflı çıkar ittifakı”, Aljazeeraturk, 17 Nisan 2015 , http://aljazeera.com.tr/gorus/husi-iran-iliskisi-mezhep-kilifli-cikar-ittifaki

Ez Zeatira, Y. (2014). 'İran’’n Elindeki Dördüncü Arap Başkenti', Aljazeera Türk, 27 Eylül 2014， http:// www.aljazeera.com.tr/gorus/iranin-elindeki-dorduncu-arap-baskenti

Fearon, J and Laitin, D. (2003). "Ethnicity, Insurgency and Civil War," The American Political Science Review, 97(1), 74-90.

Feierstein, G.M. (2018), “Iran's Role in Yemen and Prospects for Peace”, December 6, 2018, https://www.mei. edu/publications/irans-role-yemen-and-prospects-peace

Fraihat, I. (2016). Unfinished Revolutions: Yemen, Libya, and Tunisia after the Arab Spring, London: Yale University Press.

Gaddis, J. L. (1990). The Long Peace, New York: Oxford University Press.

Goldstone, J. (2011). "Understanding the Revolutions of 2011: Weakness and Resilience in Middle Eastern Autocracies” Foreign Affairs, 90/3, 8-16.

Green, D. (2011), "Protests in Yemen: President Saleh Promises Change", Febraury 2, 2011, https://www. washingtoninstitute.org/policy-analysis/view/protests-in-yemen-president-saleh-promises-change

Gulf News (2014). "Yemen Al Houthi Rebels Slam Federation Plan as Unfair”, 11 Şubat 2014, https://gulfnews. com/news/gulf/yemen/yemen-al-houthi-rebels-slam-federation-plan-as-unfair-1.1289512

Hadi,A.M.(2015). "Statementissued by theKingdom ofSaudi Arabia, the United Arab Emirates, theKingdomof Bahrain, the State ofQatar and the State of Kuwait”, 27 March 2015, https://www.securitycouncilreport. org/atf/cf/\%7b65BFCF9B-6D27-4E9C-8CD3-CF6E4FF96FF9\%7d/s_2015_217.pdf

Hart, B.H. L. (2015). Strateji Dolaylı Tutum, Çev: Selma Koçak, İstanbul: Doruk Yay.

Hill, G. (2017) Yemen Endures Civil War, Saudi Adventurism and the Future of Arabia, Newyork: Oxford University Press.

Hilterman, J ve Alley, L.A. (2017). “The Houthis Are Not Hezbollah”, Foreign Policy, Februay 27, 2017, https://foreignpolicy.com/2017/02/27/the-houthis-are-not-hezbollah/

Hughes, G. A. (2014). "Syria and the perils of proxy warfare”, Small Wars \& Insurgencies, Vol.25 No.3, 522538.

Huntington, S.P. (1993). “Clash of Civilizations”, Foreign Affairs; Summer, 1993/72, 3 - 22.

Hürriyet (2015) “İran Yemen’e Silah Gönderdiği İddialarını Yalanladı”, 31 Mart 2015,

http://www.hurriyet.com.tr/dunya/iran-yemene-silah-gonderdigi-iddialarini-yalanladi-28603769

International Crisis Group (2014). “The Huthis: From Saada to Sanaa”, Middle East Report, No.154, 10 Haziran 2014, Brussel.

Juneau, T. (2016). "Iran's policy towards the Houthis in Yemen: A limited return on a modest

investment", International Affairs, 92: 3, pp. 647-663.

Kadercan, B. (2018). "What the ISIS Crisis Means for the Future of the Middle East", in (Eds). Yeşiltaş, M., Kardaş, T., Non-State Armed Actors in the Middle East, London: Palgrave Macmillan, pp. 237-261. 
Kempe, F. and Reyes, C. (2018). Risk Nexus: Overcome by cyber risks? Economic benefits and costs of alternate cyber futures, Washington: Atlantic Council.

Kube,C., Windrem, R., and Arkin, W.M. ( 2018). "U.S. airstrikes in Yemen have increased six fold under Trump”, February 02, 2018, https://www.nbcnews.com/news/mideast/u-s-airstrikes-yemenhave-\%20increased-sixfold-under-trump-n843886

Kurt, V. (2015). ““'Devrimden Askeri Müdahaleye Yemen”, SETA Analiz 144, Aralık 2015.

Kurt, V. (2018). “Devrim İddiasından İnsani Krize Yemen”, 09.01.2018, http://ortadogudan.com/ makaleler/45/devrim-iddiasindan-insani-krize-yemen/

Lewis, A. (2015). Security, Clans and Tribes: Unstable Governance in Somaliland, Yemen and the Gulf of Aden, London: Palgrave.

Marshall, A. (2015). "From civil war to proxy war: past history and current dilemmas", Small Wars \& Insurgencies, 27:2, 183-195.

Middle East Policy Council (2015), "Houthi “Coup” Leaves Yemen on the Brink", https://mepc.org/ commentary/houthi-coup-leaves-yemen-brink

Mukhashaf, M. and Kalin, S. (2018). "Yemen civil war: Deadly clashes between separatists and government forces deepens split between Gulf allies", Independent, 28 January 2018, https:// www.independent.co.uk/news/world/middle-east/yemen-civil-war-saudi-arabia-riyadh-uaedubai-iran-houthis-aden-middle-east-cold-war-latest-a8182141.html

Mumford, A. (2013a). "Proxy Warfare and the Future of Conflict”, The RUSI Journal, Vol. 158, No:2, 40 46.

Mumford, A. (2013b). Proxy Warfare, Cambridge: UK: Polity Press.

Mumford, A. (2017). “The New Era of the Proliferated Proxy War", The Strategy Bridge, https:// thestrategybridge.org/the-bridge/2017/11/16/the-new-era-of-the-proliferated-proxy-war

New America (2018). “Drone Strikes: Yemen”, 29.07.2018,

https://www.newamerica.org/in-depth/americas-counterterrorism-wars/us-targeted _ killingprogram-yemen/

NTV (2011). “Yemen'de mutlu son!", 22.11.2011, https://www.ntv.com.tr/dunya/yemendemutlu-son,RKKGAM12PU27Tl0QwkRK5w

NTV (2015). “İran Yemen'de Husilere yardım gönderdi”, 31.03.2015 https://www.ntv.com.tr/dunya/iranyemende-husilere-yardim - gonderdi\%2cnH_HXTiMAUespScyog3Wzw

OSSGY (2013). “National Dialogue Conference”,

https://osesgy.unmissions.org/national-dialogue-conference

Ottaway, D. (2015). “Interview with David Ottaway", Pomeas, 13 Temmuz 2015, https://www.academia. edu/17852987/Interview_with_David_Ottaway

Özev, M.H. (2016). “İran-Suudi Arabistan İlişkileri 1932-2014”, İktisat Fakültesi Mecmuası, C.66, 2016/1, 83-104.

Pfaff, C. A. (2017). "Strategic Insights: Proxy War Norms", SSI Research Analysis,

December 18, 2017, http://ssi.armywarcollege.edu/index.cfm/articles/Proxy-War-Norms/2017/12/18

Pompeo, M. (2018), “After the Deal: A New Iran Strategy”, May 21, 2018, https://www.state.gov/secretary/ remarks/2018/05/282301.htm

Pollack, K. M. (2015). “The Dangers of the Arab Intervention in Yemen”, Brookings, March, 26, 2015, https://www.brookings.edu/blog/markaz/2015/03/26/the-dangers-of-the-arab-interventionin-yemen/ 
Pradhan, P. K. (2017). Arab Spring and Sectarian Faultlines in West Asia Bahrain, Yemen and Syria, New Delhi: Pentagon Press.

Rabushka, A and Shepsle, K. (2009). Politics in Plural Societies: A Theory of Democratic Instability, New York: Pearson-Longman.

Rieder, B. (2017). "Who are the Houthis, and why are we at war with them?", December 18, 2017, https:// www.brookings.edu/blog/markaz/2017/12/18/who-are-the-houthis-and-why-are-we-at-war-withthem/

Robinson, N. (2017). "Spending for success on cyber defence" NATO Review, 06.04.2017, https://www.nato. int/docu/review/2017/also-in-2017/nato-priority-spending-success-cyber-defence/en/index.htm

Salisburry, P. (2015). Yemen and the Saudi-Iranian 'Cold War', Chatham House Research Paper, February, 2015, s.1.

Sharp, J. M. (2015). "Yemen: Background and US Relations", Congressional Research Service, February 11, 2015, https://www.un.org/press/en/2012/sc10671.doc.htm

Sinkaya, B. (2015). "İran-Yemen İlişkileri ve Ensarullah Hareketi”, Ortadoğu Analiz, Cilt: 7 Sayı: 67, MartNisan 2015, 60-62.

Statista (2018a). "Number of U.S. drone strikes in Yemen from 2011 to April 2018”, 29.07.2018, https://www. statista.com/statistics/428496/us-drone-strikes-in-yemen/

Statista (2018b). "Number of United States airstrikes in Yemen between 2002 and 2018”, 29.0 7.2018 , https://www.statista.com/statistics/274007/airstrikes-in-yemen-by-the-us - since-2002/

Tertrais, B. (2012). “The Demise of Ares: The End of War as We Know It?”, The Washington Quarterly, Vol.35 No.3, 7-22.

The Embassy of Kingdom of Saudi Arabia (2015). "Statement by Saudi Ambassador Al-Jubeir on Military Operations in Yemen”, March 25, 2015, https://www.saudiembassy.net/press-release/ statement-saudi-ambassador-al-jubeir-military-operations-yemen

The White House (2013). "Letter from the President - Regarding the War Powers Resolution", June 14, 2013, https://obamawhitehouse.archives.gov/the-press-office/2013/06/14/letter-president-regardingwar-powers-resolution

Timetürk (2017). “Katar, Yemen’deki Uluslararası Koalisyon'dan çıkarıldı”, 05.06.2017, https://www.timeturk.com/katar-yemen-deki-uluslararasi-koalisyon-dan-\%20cikarildi/ haber-662119

Towle, P. (1981). “The Strategy of War by proxy”, The RUSI Journal, 126:1, 21-26.

UN Press (2012). "Security Council Demands End to All Actions Undermining Government in Yemen, Expresses Readiness to Consider 'Article 41' Measures if Necessary”, 12 June 2012, https:// www.un.org/press/en/2012/sc10671.doc.htm

Zimmerman, K and Harnisch, C. (2018). "Profile: al Houthi Movement”, January 28, 2018, https://www. criticalthreats.org/analysis/profile-al-houthi-movement 